\title{
The Impact of Credit Risk Management in the Profitability of Albanian Commercial Banks During the Period 2005-2015
}

\author{
Sokol Ndoka ${ }^{1}$, Manjola Islami ${ }^{2}$
}

\begin{abstract}
Albanian Financial institutions face difficulties for a multitude of reasons but the major cause of Albanian banking problems are related to the credit risk. For the Albanian banks, loans are the largest source of credit risk as they are not active is trading derivatives. Banks objective is to manage credit risk in order to prevent losses and to maximize its profitability.

The main purpose of this research is to study if it exist a relationship between Credit risk management and profitability of commercial banks in Albania. The main indicators used in this study are Return on Equity, Return on Assets, Non-performing Loans Ratio and Capital Adequacy Ratio. The research collects data from the 16 banks operating in the Albanian banking system from 2005 to 2015. Statistical test are performed in order to test the relationship between the four indicators and the profitability of commercial banks in Albania. This study provides a contribution within the identification of credit risk factors that affect more the profitability of the Albania Banks and the finding of a scientific solution in order to manage the credit risk in a more efficient way.
\end{abstract}

Key words: Profitability, Capital Adequacy, Return on Assets, Return on Equity, Credit risk management, Nonperforming Loans Ratio.

\section{Introduction}

Today risk plays an important role in the activity of fanancial and non-financial institutions. Almost for each decision managers and executives should calculate the expected risk and return. The effective risk management is essential for the success and continuity of business activity. In the banking system, the risk management plays an important role and regulators are responsible for controling banks risk taking in order to avoiding financial and economic crises. Among other risk, such as market risk, operational risk and legal risk etc, the major cause of banks problems are related to the credit risk.

Due to the role of credit risk on the profitability of commercial banks the main purpose of this research is to study if it exist a relationship between credit risk management and profitability of commercial banks in Albania.

In order to analyze the impact of credit risk management on the profability of commercial banks in Albania the following research questions and hypotheses are made: 


\section{Research question:}

What is the relationship between credit risk management and profitability of commercial banks in Albania during the period 2005-2015?

\section{Hypotheses:}

Hypothesis 1: NPLR (non-performing loan ratio) and CAR (capital adequancy ratio) have an impac on the ROE (return on equity) of commercial banks in Albania.

Hypothesis 2: NPLR and CAR have an impact on the ROA (return on assets) of commercial banks in Albania.

\subsection{Limitations}

Initially our study intended to analyze the data of the period 2005-2015 in order to have a larger number of observations. Indeed we collected the data from March 2007 to December 2015 because the data used for this study were available only starting from March 2007. Also we used quarterly data and not monthly data given that CAR is published by Bank of Albania every 3 months.

\section{Theorical framework}

\subsection{Definition of credit risk}

The main risk faced by the banks today is credit risk, which is defined as: "The potential that a borrower will fail to meet its obligations (principal, interests, commissions), on time or in accordance with the agreed terms "1. Banks are required by law to maintain Loan Loss Reserves 2 in order to cover the losses caused by theloans. Credit risk arises from a debtor being unlikely to pay its obligations or its financial capacity deteriorated resulting in an economic loss for the bank. The loss could be equal to the entire amount of the loan or a part of the loan granted to the borrower.

The loss results from a reduction of loan portfolio value resulting from the deterioration of actual or perceived loans quality. The real credit risk is the deviation of portfolio performance from the expected value. Credit risk is also the risk of deterioration of the financial position of the issuer of securities (stocks, bonds). Credit risk rise from loan agreements signed between a bank and individuals, corporations, financial institutions or state. For the majority of banks loans are the most important and most visible source of credit risk, however, credit risk derives from other banking activities such as on and off balance sheet activities3. Banks are facing credit risk also when they trade various financial instruments including: bank receipts, interbank transactions, exchange rate transactions, future, swaps and options contracts.

The credit risk can be categorized according to the reasons of the failure. For example the failure may be due to the countyr in which the bank has the exposure or as a result of problems in the performance and completion of the transactions. The bank should identify, measure, monitor and control the credit risk related to its activities and determine capital adequacy ratio.

The main objective of the Credit Risk Management is to maximize bank return adjusted

\footnotetext{
1 Orfea Odhuci, Advanced Bank Management 2009

${ }^{2}$ Loan Loss Reserve

${ }^{3}$ On and off balance sheet items
} 
to the risk and keeping an acceptable level of exposure to credit risk. The risk must be managed on "Related Parties"4 level.

\subsection{The components of credit risk management}

The effective management of credit risk is essential for the long-term success of any banking institution. The exposure to credit risk continues to be the source of problems for banks worldwide and their supervisors should be able to extract valuable lessons from past experiences. Regardless the fact that the practices related to credit risk management may vary among banks, depending on the nature, complexity of activities, of loan etc., the risk management structure will be similar.

\subsection{Credit risk management structure}

\subsubsection{Board and senior management}

It is the responsibility of the bank's board to approve key policies, procedures and strategies related to credit risk and its management, which should be based on the basic strategy of the bank. The strategy should be reviewed by the board, preferably once a year.

The strategies and policies must:

a. Describe the bank's general tolerance against credit risk.

b. Ensure that the overall exposure against credit risk is kept at prudential levels and consistent to the bank capital.

c. Ensure that senior management and individuals responsible for credit risk management has the necessary skills and knowledge to perform successful risk management functions.

The primary objective of the bank's credit strategy is to determine the bank's appetite for risk. Once determined the risk acceptance level, the bank develops plans to optimize the return keeping the credit risk within predefined levels. The credit risk strategy should include:

a. The bank plans to grant loans based on different client segments, products, economic sectors, geographical location, currency and credit terms.

b. The target market, the preferred level of diversification and concentration.

c. Strategy of prices.

The strategy should take in consideration consistently the country's economic cycles and change it according to the composition and quality of loan portfolio. On the other hand, the strategy should be sustainable in long terms.

The senior management creates and develops policies and procedures for loan administration and gets approval for these policies from the board of directors and they are responsible for their implementation. Policies and procedures should be clear and

4Related Parties: Two or more individuals or legal entities 1) where one has control over the other, directly or indirectly, or 2) are connected in such a way that the deterioration of the financial situation of one can lead the other to the same situation, because losses, gains or paying capacity can be easily transferred to the other/others. 
communicated to all hierarchical levels and serve as a guide for staff related to loan approval process.

\subsubsection{Organizational structure}

The organizational structure should be in line with bank's size, complexity and activities. Each bank creates Credit Risk Management Committee which is responsible for implementing policies and procedures approved by the board and establishing acceptable levels of exposure to credit risk. Also this committee monitors credit risk, recommends policies and procedures, sets the delegation of competences for loan approval to bank staff (lending limits), define standards for collaterals, risk concentration, risk monitoring and assessment, loan pricing, provisions, rules in compliance with the law.

Banks should establish the Department of Credit Risk Management, which ensures that the undertaken risk is within the limits established by Credit Risk Management Committee, ensures that the business line is in accordance with risk parameters. They are also responsible for creating loan loss provisions.

\subsection{The Basel Committee ${ }^{5}$}

Basel Committee has identified the areas where banks need to ensure full and fair transparency: accounting policies and practices, credit risk management, credit quality and earnings. Basel Committee monitors banks for credit risk transparency. Basel II has established regulation about the level of regulatory capital for financial institutions in order to cover potential losses. Three ways are proposed to the banks in order to calculate of credit risk component. The first is the standardized approach and the second is foundation $\mathrm{IRB}^{6}$ and advanced IRB.

\section{Methodology and model of the research}

The study analyze 36 observations, which include quarterly data from March 2007 to December 2015. The data used are secondary data published by the Bank of Albania:

1. $R O E$ is the return on equity which shows the net profit level generated by the equity invested in the bank. ROE is a dependent variable and it is expressed as a $\%$.

2. $R O A$ is the return on assets. ROA indicator shows how well the bank's assets are used to generate higher profits. ROA is a dependent variable and it is expressed as a $\%$.

3. $\quad \boldsymbol{N P L R}$ is non-performing loan ratio of the banking system and is expressed through the ratio of non-performing loans outstanding to total loans outstanding. It is an independent variable and it is expressed as a $\%$.

${ }^{5}$ Basel Committee on Banking Supervision, Bank for International Settlements. 2008. Principles for Sound Liquidity

Risk Management and Supervision (http://www.bis.org/publ/bcbs144.htm)

${ }^{6}$ Internal ratings based. 
4. $\quad C A R$ represents the capital adequancy ratio and it is defined as the ratio of banks tier $1+$ tier 2 capital to the risk-weighted assets. Also CAR is an independent variable and it is expressed as $\mathrm{a} \%$.

Table 1: Summary of variables

\begin{tabular}{|c|c|c|c|}
\hline & Variable & Calculation Method & Indicator \\
\hline \multirow{2}{*}{$\begin{array}{l}\text { Dependent } \\
\text { variables }\end{array}$} & ROE & Net profit/Equity & Indicator of profitability \\
\hline & ROA & Net profit/Assets & Indicator of profitability \\
\hline \multirow[t]{2}{*}{$\begin{array}{l}\text { Independent } \\
\text { variables }\end{array}$} & NPLR & $\begin{array}{l}\text { Non-performing loan / total } \\
\text { loans }\end{array}$ & $\begin{array}{l}\text { Indicator of credit risk } \\
\text { management }\end{array}$ \\
\hline & CAR & $\begin{array}{l}\text { bank's tier one capital }+ \text { tier } \\
\text { two capital / RWAs }\end{array}$ & $\begin{array}{l}\text { Indicator of credit risk } \\
\text { management }\end{array}$ \\
\hline
\end{tabular}

Source: Authors, 2016

In order to determine the effect of credit risk management on banks profitability the Ordinary least squares (OLS) methode is used through applying the statistical program Eviews on the quantitative data published by the Bank of Albania for the period March 2007 - December 2015.

A regression model is employed in order to analyze the relation between NPLR \& CAR and ROA \& ROE:

$\mathbf{Y}_{\mathrm{i}}=\beta_{0}+\beta_{1} \mathbf{X}_{\mathrm{i}}+\mathbf{u}_{\mathrm{i}}$

As the study has more than one independent variable a multiple regression model should be employed. The regression equation will be:

$\mathbf{Y}_{\mathrm{i}}=\beta_{0}+\beta_{1} \mathbf{X}_{\mathrm{i}}+\boldsymbol{\beta}_{2} \mathbf{X}_{\mathrm{i}}+\boldsymbol{\beta}_{3} \mathbf{X}_{\mathrm{i}}+\ldots . .+\boldsymbol{\beta}_{\mathrm{n}} \mathbf{X}_{\mathrm{i}}+\mathbf{u}_{\mathrm{i}}$

Based on the above equation and the variables used in this study, the econometric equation for the model is specified as following:

- $\quad$ First hypothesis:

$\operatorname{ROE}_{\mathrm{t}}=\beta_{0}+\beta_{1} \mathrm{NPLR}_{\mathrm{t}}+\beta_{2} \mathrm{CAR}_{\mathrm{t}}+\mathrm{u}_{\mathrm{i}}$

- Second hypothesis:

ROAt $=\beta 0+\beta 1 \mathrm{NPLRt}+\beta 2 \mathrm{CARt}+\mathrm{ui}$

Where, NPLR $=$ non-performing loan ratio, $C A R=$ capital adequacy ratio, $\mathrm{ROE}=$ return on equity, $\mathrm{ROA}=$ return on assets and $\mathrm{u}_{\mathrm{i}}=$ error term.

\section{Analysis and data interpretation}

To test the 2 hypotheses of this research the following variables are analyzed:

a. dependent variables (ROA and ROE) ; and

b. independent variables (NPLR and CAR).

The model is based on the analysis of a multiple regression equation and statistical program Eviews is applyed on the data. The results of the tests are presented in the following tables for each of the two hypotheses.

Hypothesis 1: NPLR and CAR have an impac on the ROE of commercial banks in Albania:

$\operatorname{ROE}_{\mathrm{t}}=\beta_{0}+\beta_{1} \mathrm{NPLR}_{\mathrm{t}}+\beta_{2} \mathrm{CAR}_{\mathrm{t}}+\mathbf{u}_{\mathrm{i}}$ 
Table 2: Results for the first hypothesis

\begin{tabular}{lllll}
\hline \hline Variable & Coefficient & Std. Error & t-Statistic & Prob. \\
\hline \hline C & -1.077055 & 1.369302 & -0.786572 & 0.4371 \\
NPLR & -0.018582 & 0.011006 & -1.688355 & 0.0108 \\
CAR & -0.128753 & 0.079806 & 1.613333 & 0.1162 \\
\hline \hline R-squared & 0.173664 & Mean dependent var & 0.770507 \\
Adjusted R-squared & 0.123583 & S.D. dependent var & 0.529939 \\
S.E. of regression & 0.496114 & Akaike info criterion & 1.515633 \\
Sum squared resid & 8.122258 & Schwarz criterion & 1.647593 \\
Log likelihood & -24.28139 & Hannan-Quinn criter. & 1.561691 \\
F-statistic & 3.467663 & Durbin-Watson stat & 0.631081 \\
Prob(F-statistic) & 0.042962 & & \\
\hline \hline
\end{tabular}

Source: Author's computation, 2016

F-statatistic, which measures the common importance of the explanatory variables, is statistically significant at the $5 \%$ level, according to the corresponding value of probability 0,042962. According to this, the model used is appropriate. Results show that the coefficient NPLR is statistically significant at the $5 \%$ level with a probability of 0.0108 and implies an negative correlation between the variables. Keeping all other coefficients constant, an increase of 1 unit in the variable NPLR will lead to a reduction in the variable ROE by 0.018582 units. A higher level of bad loans means more losses for the bank and therefore a smaller profit.

The regression analysis shows that the probability of CAR coefficient is 0.1162 . Based on the fact that the level of significance is 5 per cent, a probability greater than $5 \%$ indicates that the variable is not statistically significant.

Adjusted $\mathrm{R}^{2} 0.123583(12,35 \%)$ suggests that $12.35 \%$ of the total variation in ROE of commercial banks in Albania is explained by joint variations in the independent variables. In conclusion the results of the regression analysis shows that the correlation between ROE and CAR is statistically insignificant and the correlation between ROE and NPLR is significant statistically and this correlation is negative.

Hypothesis 2: NPLR and CAR have an impac on the ROA of commercial banks in Albania:

$\mathbf{R O A}_{t}=\beta_{0}+\beta_{1} \mathrm{NPLR}_{\mathrm{t}}+\beta_{2} \mathrm{CAR}_{\mathrm{t}}+\mathbf{u}_{\mathrm{i}}$

Table 3: Results for the second hypothesis

\begin{tabular}{lllll}
\hline \hline Variable & Coefficient & Std. Error & t-Statistic & Prob. \\
\hline \hline C & -17.49850 & 16.63875 & -1.051672 & 0.3006 \\
NPLR & -0.286940 & 0.133738 & -2.145539 & 0.0394 \\
CAR & -1.878732 & 0.969739 & 1.937358 & 0.0613 \\
\hline \hline R-squared & 0.243463 & Mean dependent var & 9.219584 \\
Adjusted R-squared & 0.197612 & S.D. dependent var & 6.729932
\end{tabular}




\begin{tabular}{llll} 
S.E. of regression & 6.028410 & Akaike info criterion & 6.510499 \\
Sum squared resid & 1199.277 & Schwarz criterion & 6.642459 \\
Log likelihood & -114.1890 & Hannan-Quinn criter. & 6.556556 \\
F-statistic & 5.309909 & Durbin-Watson stat & 0.597319 \\
Prob(F-statistic) & 0.010016 & & \\
\hline \hline
\end{tabular}

Source: Author's computation, 2016

F-statatistic is statistically significant at the $5 \%$ level, according to the corresponding value of probability 0.010016 . According to this, the model used is appropriate. Results show that the coefficient NPLR is statistically significant at the $5 \%$ level with probability 0.0394 and implies an negative correlation between the variables. Keeping all other coefficients constant, an increase of 1 unit in the variable NPLR will lead to a reduction in the variable ROA by 0.286940 units. A higher level of bad loans means more losses for the bank and therefore a smaller profit.

The regression analysis shows that the probability of CAR coefficient is 0.0613 . Based on the fact that the level of significance is 5 per cent, a probability greater than $5 \%$ indicates that the variable is not statistically significant.

Adjusted $\mathrm{R}^{2} 0.243463(24,35 \%)$ suggests that $24.35 \%$ of the total variation in ROA of commercial banks in Albania is explained by joint variations in the independent variables. In conclusion, the results of the regression analysis show that the correlation between ROA and CAR is statistically insignificant and the correlation between ROE and NPLR is statistically significant and this correlation is negative.

\section{Conclusions/ Recommendations}

This paper studies the impact of credit risk management on the profitability of commercial banks in Albania during the period 2007-2015. To analyze the relationship between credit risk management and profitability of banks secondary data published by the Bank of Albania were collected for 16 commercial banks operating in Albania during the period 2007-2015. ROE and ROA are used as indicators to measure the profitability of banks and NPLR and CAR as indicators of credit risk management. Statistical program Eviews was applied on the collected data (36 observations/quarterly data) to test the 2 hypotheses of this research.

The econometric results confirmed that there exist a correlation between the credit risk management of commercial banks in Albania and their profitability. A more efficient credit risk management will lead to higher profit for the Albanian commercial banks.

The results of the regression analysis indicate that the correlation between CAR and ROA and CAR and ROE is not statistically significant. Other studies, as Kithinji (2010) in Kenya, have also failed to prove the correlation between CAR and ROA. The systematic risk during the financial crisis of 2008 could be one of the factors that lead to this result.

Also the results of the regression analysis show that there exist a negative correlation between NPLR and ROA and NPLR and ROE and this correlation is statistically significant. Keeping all other coefficients constant, an increase of 1 unit in the variable 
NPLR will lead to a reduction in the variable ROA by 0.286940 units and a reduction in the variable ROE by 0.018582 units. This result is in accordance with the literature and is explained with the fact that a greater NPLR means less capital available for the banks to invest.

Based on these results the commercial banks in Albania should be more focused on credit risk management, especially on the control and monitoring of non-performing loans.

\section{References}

Abiola, I. and Olausi, A.S. (2014). The Impact of Credit Risk Management on the Commercial Banks Performance in Nigeria, International Journal of Management and Sustainability, 3 (5), pp. 295-306.

Albanian Association of Banks, Statistics, (available at www.aab.al)

Al-Khouri, R. (2011). Assessing the risk and performance of the GCC banking sector, International Research Journal of Finance and Economics, 65, 72-78.

Angbazo, L. (1997). Commercial Bank Net Interest Margins, Default Risk, Interest Rate Risk and Off-Balance Sheet Banking. Journal of Banking and Finance, 21, 55-87.

Banka e Shqiperise, Statistics, (available at www.bankofalbania.org)

Basel Committee on Banking Supervision. (2008). Principles for Sound Liquidity Risk. Management and Supervision. (available at www.bis.org).

Berger, A.N., DeYoung, R.. (1997). Problem loans and cost efficiency in commercial banks, Journal of Banking and Finance 21(6), 849-70.

Bernanke, Ben. (1983). Nonmonetary effects of the financial crisis in the propagation of the Great Depression. American Economic Review, 73, 257-76.

Berger, A. (1995). The relationship between capital and earnings in banking. Journal of Money, Credit and Banking, Vol.27.

Bozdo, A. (2012). The role of Central Bank in Financial Institutions protection from global financial crises through effective supervision.

Dougherty C. (2011). Introduction to Econometrics, OUP Oxford.

Drehman, M., Sorensen, S. \& Stringa, M. (2008). The Integrated Impact of Credit and Interest Rate Risk on Banks: An Economic Value and Capital Adequacy Perspective, Bank of England Working Paper No.339

Epure, M. and Lafuente, I. (2012). Monitoring Bank Performance in the Presence of Risk, Barcelona GSE, Working Paper Series No.61.

Kithinji, A. M. (2010). Credit Risk. Management and Profitability of Commercial Banks in Kenya, School of Business, University of Nairobi, Kenya.

Levine, Ross. (1997). Financial Development and Economic Growth. Journal of Economic Literature, 35 (2).

Naceur, B. Samy. (2003). The determinants of the Tunisian Banking Industry profitability: Panel evidence. Universite Libre de Tunis, Department of Finance, Working Paper 2003.

Psillaki, M., Tsolas, I.E. and Margaritis, D. (2010). Evaluation of Credit Risk Based on Firm Performance, European Journal of Operational Research, 201(3), 873-888.

Saunders, A. \& Cornett, M. M. (2008). Financial Institutions management. Southern Illinois University, McGraw 2008.

Odhuci O..(2009), Advanced Bank Management. 